\title{
Determination of 4-Nonylphenol in Surface Waters of the Guandu River Basin by High Performance Liquid Chromatography with Ultraviolet Detection
}

\author{
Frederico G. de Araujo, ${ }^{a}$ Glauco F. Bauerfeldt ${ }^{a}$ and Yara P. Cid ${ }^{*, b}$ \\ ${ }^{a}$ Departamento de Química, Universidade Federal Rural do Rio de Janeiro, 23890-000 Seropédica-RJ, Brazil \\ ${ }^{b}$ Departamento de Ciências Farmacêuticas, Universidade Federal Rural do Rio de Janeiro, \\ 23890-000 Seropédica-RJ, Brazil
}

\begin{abstract}
4-Nonylphenol, a degradation product of ethoxylated alkylphenols, due to its harmful effects on the environment, has been banned in European Union countries, alongside their precursors. The guide on quality of drinking water from the United States Environmental Protection Agency (US EPA) recommends a maximum concentration of $28 \mu \mathrm{g} \mathrm{L}^{-1}$ for fresh water. In Brazil, there is no clear legislation containing values of maximum concentration of 4-nonylphenol. Due to this lack of regulation, a continuous monitoring is necessary for this pollutant in environmental samples. The occurrence of 4-nonylphenol (4-NP) in the surface waters of Guandu River in the state of Rio de Janeiro, Brazil, was studied by using solid-phase extraction and reversed phase liquid chromatography separation with UV detection. The analytical method satisfies these requirements, being able to detect and quantify 4-NP in a desired concentration range. Of the 19 samples analyzed, 4-nonylphenol was detected in 12, quantified in 2, showing concentration levels of 1.73 and $2.32 \mu \mathrm{g} \mathrm{L}^{-1}$ in Santa Cruz and Paracambi, respectively. This is the main hydrographic basin in the state of Rio de Janeiro, where water is collected for treatment and later distributed to most cities in the metropolitan region, including Rio de Janeiro City, and these results are therefore alarming.
\end{abstract}

Keywords: 4-nonylphenol, Guandu River basin, HPLC-UV, aqueous sample

\section{Introduction}

Environmental pollution resulting from the release of organic compounds poses a serious threat to human health and aquatic organisms due to acute and chronic toxicity. ${ }^{1-3}$ Such pollutants are emitted from a variety of sources, which includes agricultural, industrial and urban activities.

Regarding the agricultural activity, pesticides are particularly harmful due to their long persistence in aquatic soils and sediments, bioaccumulation in the tissues of invertebrates and vertebrates, and movement in the trophic chains. ${ }^{4}$ Surfactants are usually present in agrochemical formulations ${ }^{5,6}$ and are directly released in a sewage system or in surface water causing pollution and forming degradation products. ${ }^{7}$

Alkylphenol ethoxylates (APEO), non-ionic surfactants, have been widely used in phenolic resins, plastics additives, detergents, emulsifiers, pesticides formulations among others. The most relevant APEO is nonylphenol ethoxylate (NPnEO), representing approximately $80 \%$ of production, of which $60 \%$ has the environment as a final destination. ${ }^{8-10}$

*e-mail: yarapcid@gmail.com
4-Nonylphenol (4-NP) is formed during anaerobic breakdown of the APEO. Studies have demonstrated that derivatives of ethoxylated alkylphenols are more persistent and toxic than the parent substances, also having the ability to cause disruption of natural hormones when interacting with estrogen receptor. ${ }^{8}$

As of now, there is no specific regulation in Brazil regarding the maximum permissible concentration levels of 4-NP in surface waters. Moreover, few works have carried out investigations of 4-NP in Brazilian waters, which provides little data on the matter. For instance, 4-NP has not been detected in surface water samples of four reservoirs southwest of São Paulo (limit of detection (LOD) has not been reported), although it was quantified in sediments from these sites, in concentration levels ranging from 0.1 to $3.1 \mu \mathrm{g} \mathrm{kg}^{-1} .{ }^{11}$ The occurrence of 4-NP in sediments and fish has also been recently reported by Errico et al.,${ }^{12}$ who concluded that phenolic endocrine disruptors chemicals (EDCs) have a tendency to adsorb and deposit onto sediments in aquatic environment.

Montagner and Jardim ${ }^{13}$ have reported results for the investigation of several pharmaceuticals and endocrine disruptors in the Atibaia River, São Paulo State, based on 
an optimized analytical method using solid-phase extraction (SPE) and high performance liquid chromatography (HPLC) with detection through ultraviolet-diode array (UV-DAD) or fluorescence (FLD). Selected compounds included acetaminophen, acetylsalicylic acid, diclofenac, ibuprofen, caffeine, 17 $\beta$-estradiol, estrone, progesterone, $17 \alpha$-ethynylestradiol, levonorgestrel, diethylphthalate, dibutylphthalate, 4-octylphenol, 4-nonylphenol and bisphenol A. In particular, the limit of quantification (LOQ) and LOD for 4-NP were reported as 59 and $18 \mathrm{ng} \mathrm{L}^{-1}$, respectively. Despite the low LOQ and LOD values, 4-NP was not detected in these samples. ${ }^{13}$ Sodré et al. ${ }^{14}$ have also studied the occurrence of estrone, 17 $\beta$-estradiol, estriol, $17 \alpha$-ethynylestradiol, bisphenol A, 4- $n$-octylphenol, and 4-nonylphenol in Brazilian water samples collected along the Atibaia River basin, in the state of São Paulo. In their work, liquid chromatography (LC) followed by tandem mass spectrometry (MS/MS) was applied and the reported LOD and LOQ values for 4-NP were 0.04 and $0.1 \mathrm{ng} \mathrm{L}^{-1}$, respectively. 4-NP has also not been detected in these samples. ${ }^{14}$ The concentration of 4-NP in surface water has been reported as $1.24 \mathrm{ng} \mathrm{L}^{-1}$ at a sampling point located in the Atibaia River, upstream of the city of Campinas, a one million inhabitant metropolis. The compound has also been detected in drinking water at the same sampling point, but at a concentration level below the LOQ. ${ }^{15} 4-\mathrm{NP}$ has not been detected above $2.0 \mathrm{ng} \mathrm{L}^{-1}$ in none of the 100 drinking water samples or 7 source water samples collected from 21 state capitals and the federal district in 2011 and 2012. ${ }^{16}$

Moreira et al. ${ }^{17}$ have studied the occurrence of 4-NP in water sources of Belo Horizonte metropolitan area, Brazil, reporting that the analyte was detected in all samples in a concentration range of 44 to $1918 \mathrm{ng} \mathrm{L}^{-1}$. Similar concentration range has been reported for 4-NP in waters from Rio das Velhas, located between Ouro Preto and Nova Lima, Minas Gerais State, Brazil, two years later. ${ }^{18}$

Seeing as the data related to the investigation of 4-NP in Brazilian waters is scarce, the objective of this work was to develop and validate an analytical method for the determination of this analyte in surface water and to apply it to environmental real samples. Moreover, it is an aim of this work the study of the occurrence of 4-NP in the catchment area of Guandu River in Rio de Janeiro. The Guandu River basin is of fundamental importance for the metropolitan region of Rio de Janeiro, since it encompasses fifteen municipalities in an integral and partial way, serving as a source of water for human supply and also for the industry (steel, petrochemical, food and beverages, and clothing). ${ }^{19}$

The chromatographic method was validated according to parameters of linearity, precision, accuracy, linear range and selectivity, following the validation parameters of the
United States Environmental Protection Agency (US EPA) $8000 D^{20}$ method with real samples, which may contain residues. The monitoring of 4-NP in real samples from the Guandu River basin was carried out after the validation of the method.

\section{Experimental}

Chemicals, reagents and materials

4-NP (99.9\%) and SPE Discovery 18-LT cartridges (500 mg, $3 \mathrm{~mL}$ ) were purchased from Sigma-Aldrich. Methanol, acetonitrile (HPLC grade) were purchased from Tedia, and Milli-Q (ultrapure) water was obtained from a Gehaka Master Ultra Purifier, coupled with a Gehaka OS $10 \mathrm{LZ}$ reverse osmosis purification system.

\section{Methods}

\section{Synthetic sample preparation and extraction method}

For the optimization of the extraction method, synthetic aqueous samples were prepared by fortification of water samples with the 4-NP standard solution. The synthetic aqueous samples were prepared using the surface water samples in which 4-NP had not been detected in a preliminary study. To ensure solubilization, isopropanol $(20 \mathrm{~mL})$ was added to the synthetic aqueous samples $(100 \mathrm{~mL})$.

SPE, using Discovery 18-LT cartridges, was used to promote the clean-up and pre-concentration of 4-NP in preparation of real samples. The cartridges were previously conditioned with $5 \mathrm{~mL}$ of methanol followed by $5 \mathrm{~mL}$ of water at a flow rate of $1 \mathrm{~mL} \mathrm{~min}^{-1}$. After the conditioning step, $100 \mathrm{~mL}$ of the sample was percolated along the cartridge at a flow rate of $3 \mathrm{~mL} \mathrm{~min}^{-1}$. After sample application, the analyte was eluted with $5 \mathrm{~mL}$ methanol at a flow rate of $1 \mathrm{~mL} \mathrm{~min}^{-1}$.

\section{Chromatographic conditions}

Although there are many methods described in the literature for the separation, identification and/or quantification of this analyte in several matrices, no official method has been recommended yet. Thus, the standard method US EPA $8310^{21}$ was adopted as the base and optimized the best chromatographic conditions for the separation, identification and quantification of 4-NP in surface water by HPLC-UV.

An Agilent chromatographic system composed of an Infinity 1260 HPLC with automatic injector, coupled to a DAD and UV detector with Zorbax Eclipse Plus chromatographic column $(4.6 \times 100 \mathrm{~mm}, 3.5 \mu \mathrm{m})$, 
and Agilent ChemStation Data Analysis were used in the determination. The mobile phase consisted of acetonitrile:water (90:10), in isocratic mode for $15 \mathrm{~min}$, at a constant flow of $1 \mathrm{~mL} \mathrm{~min}^{-1}$ and $10 \mu \mathrm{L}$ injection volume. The detector was set at $225 \mathrm{~nm}$.

\section{Method validation}

The precision and accuracy of the analytical method were determined by analyzing sets of 5 replicates of each of the three concentrations of synthetic samples at the concentration levels $1.15 \mu \mathrm{g} \mathrm{L}-1$ (low), $6.25 \mu \mathrm{g} \mathrm{L} \mathrm{L}^{-1}$ (medium) and $50.0 \mu \mathrm{g} \mathrm{L}^{-1}$ (high) on two consecutive days (intra-day 1 and 2). The accuracy of the method was expressed as the relative standard deviation (RSD). Accuracy was calculated by comparing the measured concentration with the nominal concentration as the mean recovery percent (\%).

The linearity was obtained by the analysis of six synthetic samples of concentrations 50.00, 25.00, 12.50, 6.25, 3.10 and $1.15 \mu \mathrm{g} \mathrm{L}^{-1}$. Following the analytical method, all the synthetic samples underwent the extraction and pre-concentration in the SPE step. The matrix effect was evaluated statistically by Student's $t$-test and by the difference between the slopes of the curves obtained for the synthetic sample after extraction and the curve obtained from the injection of the working solution. Calculation of the uncertainty of the analytical curve was performed as the ratio of the standard deviation of the area/concentration ratio values by the mean value of the area/concentration ratio values.

According to US EPA $8000 \mathrm{D}^{20}$ method, "the lower limit of quantification is the lowest concentration at which the laboratory has demonstrated target analytes can be reliably measured and reported with a certain degree of confidence, which must be $\geq$ the lowest point in the calibration curve". In our work, we assumed such definition and evaluated the LOQ by demonstrating the acceptable recovery values for synthetic samples, fortified at $1.15 \mu \mathrm{g} \mathrm{L}{ }^{-1}$, considering accuracy between 70 and $130 \%$. The LOD was then statistically evaluated by the $\mathrm{T} \times \mathrm{SD}$ product, where $\mathrm{T}$ is the Student's $t$-value appropriate for $99 \%$ confidence level and a standard deviation estimate with $(n-1)$ degrees of freedom and $\mathrm{SD}$ is the standard deviation of the quantified 4-NP concentrations of seven synthetic samples fortified at $1.15 \mu \mathrm{g} \mathrm{L} \mathrm{L}^{-1}$.

\section{Sample collection}

Nineteen surface water samples of $500 \mathrm{~mL}$ each were collected from the Guandu River and its tributaries (Canal do Itá and Ribeirão das Lajes) during April, May, and June 2015. The sampling points were selected to include the largest possible area of the river basin and to provide relevant data on the presence of 4-NP by investigating the various possible sources from various anthropogenic sources, such as municipal and industrial wastewater discharges, as well as agricultural practices or other sources.

Samples were collected in Rio de Janeiro (industrial district of Santa Cruz) (sampling point P1), Queimados (P2), Itaguaí (P3), Seropédica (P4), Paracambi (P5), Japeri (P6) and Piraí (P7). The location of the points is shown in Figure 1 and the dates are listed in Table 1.

\section{Results and Discussion}

\section{Method validation}

\section{Selectivity}

Selectivity was obtained by injecting a synthetic sample (matrix and 4-NP) and injecting a blank (matrix only). The chromatograms of the two injections (Figure 2) were evaluated and the absence of signal in the chromatogram of the blank injection was verified, at the same retention time of the 4-NP seen in the injection of the synthetic sample. Thus, the matrix does not present any signal at the same retention time of the analyte, making it selective for the presence of 4-NP in the studied matrix. The developed methodology is, therefore, capable of detecting and/or quantifying the analyte.

Method quantification limit (MQL) and method detection limit (MDL)

The MDL and MQL were, respectively, 0.20 and $1.15 \mu \mathrm{g} \mathrm{L}-1$ (Table 2). The MDL and MQL of the method are quite consistent with methods available in the literature ${ }^{22-24}$ and US EPA 8000D method..$^{20}$

The analytical method proposed here is capable of quantifying 4-NP in surface water samples, in concentration levels above $1.15 \mu \mathrm{g} \mathrm{L}{ }^{-1}$ (our validated limit of quantification), which is close to the upper limit of the reported concentration range for 4-NP, found in Rio das Velhas and at Belo Horizonte Metropolitan Area, Minas Gerais. ${ }^{17,18}$ If our method had been applied to those samples, 4-NP would certainly not be quantified in several of them. We note that, in our work, a concentration factor of 20 has been used $(100 \mathrm{~mL}$ of the sample, $5 \mathrm{~mL}$ eluted). A higher concentration factor could be achieved by using larger sample volumes and a tentative concentration factor of 400 would be suitable for monitoring 4-NP in Rio das Velhas and other sites (including the Guandu River basin).

As mentioned above, there is no guide or recommendation in Brazil concerning the maximum allowed values of 4-NP in surface, drinking or groundwater. The US EPA, however, provides aquatic life ambient water quality criteria, which are the highest concentration of specific 


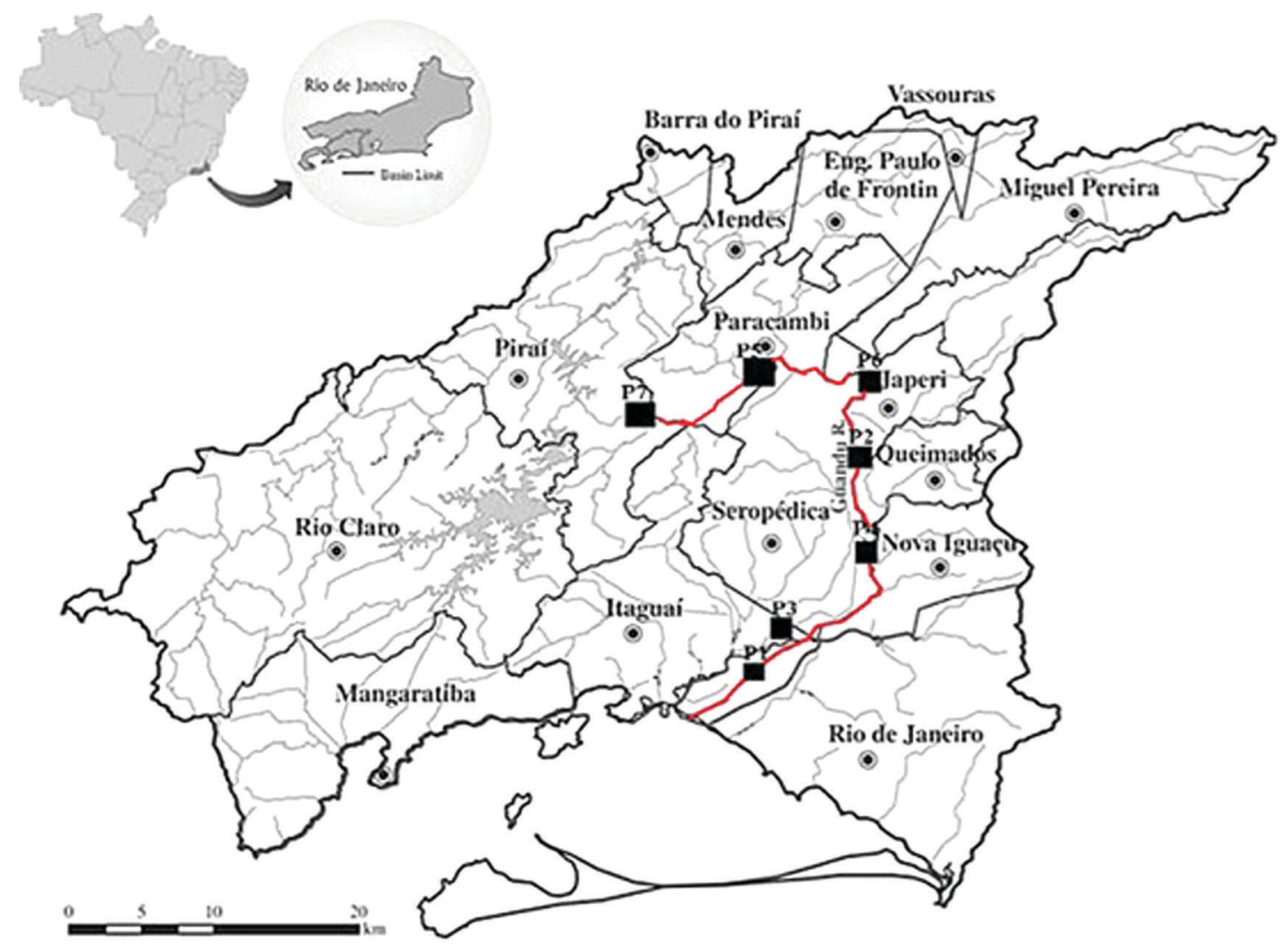

Figure 1. Location of the sampling points of surface water.

Table 1. Geographic coordinates and collection period of each sampling point

\begin{tabular}{|c|c|c|c|}
\hline Location (description) $^{\mathrm{a}}$ & Coordinate & Period & Year \\
\hline \multirow[t]{3}{*}{ Rio de Janeiro (Santa Cruz District, P1, G) } & $22^{\circ} 53^{\prime} 48.55^{\prime \prime} \mathrm{S}$ & April & 2015 \\
\hline & $43^{\circ} 44^{\prime} 13.58^{\prime \prime} \mathrm{W}$ & May & \\
\hline & & June & \\
\hline \multirow[t]{3}{*}{ Queimados (P2, G) } & $22^{\circ} 43^{\prime} 38.89^{\prime \prime} \mathrm{S}$ & April & 2015 \\
\hline & $43^{\circ} 38^{\prime} 26.55^{\prime \prime} \mathrm{W}$ & May & \\
\hline & & June & \\
\hline \multirow[t]{2}{*}{ Itaguaí (P3, CI) } & $22^{\circ} 53^{\prime} 33.36^{\prime \prime} \mathrm{S}$ & June & 2015 \\
\hline & $43^{\circ} 41^{\prime} 40.89^{\prime \prime} \mathrm{W}$ & & \\
\hline \multirow[t]{3}{*}{ Seropédica (P4, G) } & $22^{\circ} 48^{\prime} 58.53^{\prime \prime S}$ & April & 2015 \\
\hline & $43^{\circ} 37^{\prime} 29.77^{\prime \prime} \mathrm{W}$ & May & \\
\hline & & June & \\
\hline \multirow[t]{3}{*}{ Paracambi (P5, RL) } & $22^{\circ} 40^{\prime} 06.67^{\prime \prime S}$ & April & 2015 \\
\hline & $43^{\circ} 44^{\prime} 56.26^{\prime \prime} \mathrm{W}$ & May & \\
\hline & & June & \\
\hline \multirow[t]{3}{*}{ Japeri $(\mathrm{P} 6, \mathrm{G})$} & $22^{\circ} 39^{\prime} 03.40^{\prime \prime} \mathrm{S}$ & April & 2016 \\
\hline & $43^{\circ} 38^{\prime} 03.40^{\prime \prime} \mathrm{W}$ & May & \\
\hline & & June & \\
\hline \multirow[t]{3}{*}{ Piraí (P7, RL) } & $22^{\circ} 69^{\prime} 04.26^{\prime \prime} \mathrm{S}$ & April & 2017 \\
\hline & $43^{\circ} 80^{\prime} 00.34^{\prime \prime} \mathrm{W}$ & May & \\
\hline & & June & \\
\hline
\end{tabular}

aP1-P7: sampling points in Rio de Janeiro State; G: Guandu River; RL: Ribeirão das Lajes; CI: Canal do Itá. 

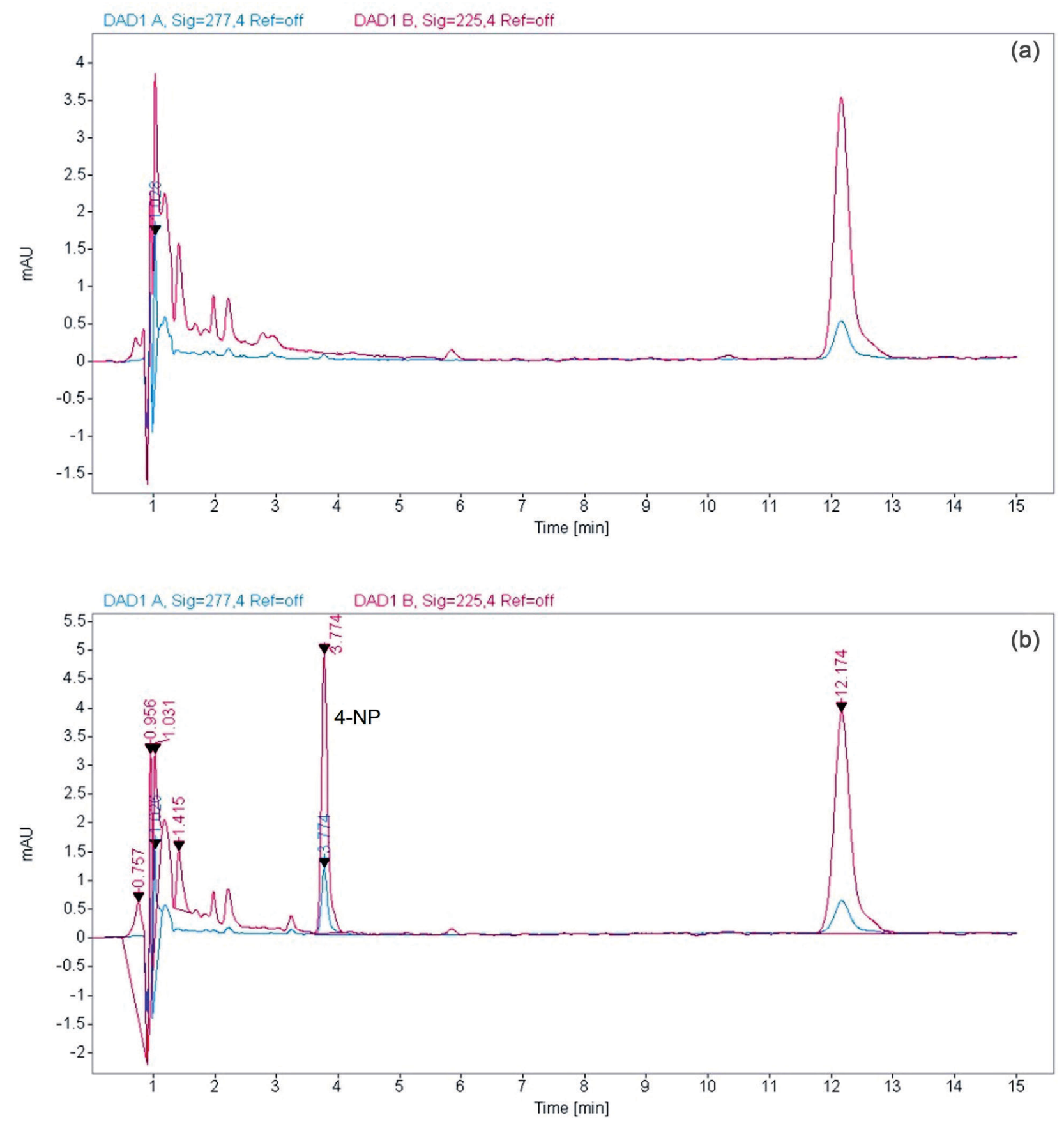

Figure 2. Chromatogram with optimized conditions of the (a) blank (matrix only) and (b) synthetic sample (matrix and 4-nonylphenol).

pollutants or parameters in water that are not expected to pose a significant risk to the majority of species in a given environment. In such guide, the national recommended aquatic life criteria for $4-\mathrm{NP}$ is $28 \mu \mathrm{g} \mathrm{L}^{-1}$, based on a maximum concentration criterion, and $6.6 \mu \mathrm{g} \mathrm{L}^{-1}$, based on a continuous concentration criterion, for freshwater. ${ }^{25}$ Since our work has been devoted to investigate 4-NP in water samples collected along the Guandu River basin, and taking into account the US EPA aquatic life criteria, our LOQ could be considered good enough.
According to Azevedo et al. ${ }^{26}$ 4-NP is commonly found in surface waters in the concentration range from 0.20 to $12.00 \mu \mathrm{g} \mathrm{L}^{-1}$, and concentrations higher than $10.00 \mu \mathrm{g} \mathrm{\textrm {L } ^ { - 1 }}$ can cause estrogenic effects in fish. Based on a chronic exposure of $C$. silvestrii to 4-NP test, the estimated values for the highest concentration that had no effect (NOEC) and for the lowest concentration that had a deleterious effect on reproduction (LOEC) were 0.015 and $0.019 \mathrm{mg} \mathrm{L}^{-1}$, respectively. ${ }^{27}$ These values are ca. 10 times our MQL and are in agreement with the 
Table 2. Parameter validation of the methodology developed

\begin{tabular}{|c|c|c|c|c|c|}
\hline & \multirow{2}{*}{ Fortified level / $\left(\mu \mathrm{g} \mathrm{L}^{-1}\right)$} & \multirow{2}{*}{ Parameter } & \multicolumn{2}{|c|}{ Intra-day } & \multirow{2}{*}{ Inter-day } \\
\hline & & & Day 1 & Day 2 & \\
\hline & & a & 0.745 & 0.741 & 0.738 \\
\hline & & $\mathrm{b}$ & 0.068 & 0.088 & 0.222 \\
\hline \multirow[t]{4}{*}{ Linearity } & $1.15-50.00$ & $\mathrm{r}$ & 0.9989 & 0.993 & 0.995 \\
\hline & & error & 0.054 & 0.046 & 0.026 \\
\hline & & uncertainty & 14.40 & 14.41 & 14.44 \\
\hline & 1.15 & $\mathrm{n}=5$ & 79.8 & 84.52 & 82.15 \\
\hline \multirow[t]{3}{*}{ Accuracy / \% } & 6.25 & $\mathrm{n}=5$ & 83.07 & 96.73 & 89.90 \\
\hline & 50.0 & $\mathrm{n}=5$ & 81.65 & 82.97 & 82.24 \\
\hline & 1.15 & $\mathrm{n}=5$ & 4.44 & 12.20 & 9.60 \\
\hline \multirow[t]{2}{*}{ Precision / (\%RSD) } & 6.25 & $\mathrm{n}=5$ & 5.03 & 12.92 & 9.91 \\
\hline & 50.00 & $\mathrm{n}=5$ & 4.58 & 14.30 & 10.40 \\
\hline \multicolumn{3}{|c|}{ Method quantification limit / $\left(\mu \mathrm{g} \mathrm{L} \mathrm{L}^{-1}\right)$} & \multicolumn{2}{|c|}{1.15} & \\
\hline \multicolumn{3}{|c|}{ Method detection limit / $\left(\mu \mathrm{g} \mathrm{L}^{-1}\right)$} & \multicolumn{2}{|c|}{0.20} & \\
\hline
\end{tabular}

RSD: relative standard deviation.

previously estimated value $\left(10 \mu \mathrm{g} \mathrm{L}^{-1}\right)$. Furthermore, the concentration at which the NOEC does not exceed $5 \%$ of the species population $\left(\mathrm{HC}_{5}\right)$ estimate for $4-\mathrm{NP}$ is reported as $1.39 \mu \mathrm{g} \mathrm{L}^{-1}$. Taking such value into account and an assessment factor of 5, as the worst-case scenario, for the evaluation of the predicted no-effect concentration (PNEC) value, the result of $0.28 \mu \mathrm{g} \mathrm{L}^{-1}$ is obtained, below our MQL. However, as stated by Spadoto et al.,$^{27}$ concentrations lower than $1.39 \mu \mathrm{g} \mathrm{L}^{-1} 4-\mathrm{NP}$ are not expected to adversely impact aquatic organisms in natural ecosystems. Considering these estimates and the US EPA recommendation, we believe that our reported MQL is good enough for monitoring the 4-NP in surface waters and even for a risk assessment, since it is higher than the US EPA aquatic life ambient water quality criteria and the most recent NOEC and LOEC estimates.

\section{Linearity}

A procedure to assess linearity by the ordinary least squares method was used. The linear response of the method was observed through the concentration range of 1.15 to $50.00 \mu \mathrm{g} \mathrm{L} \mathrm{L}^{-1}$ with mean correlation coefficient $\mathrm{r}=0.9955 \pm 0.025$, with uncertainty below $15 \%$ (Table 2). The linear ranges of the method are quite consistent with methods available in the literature. ${ }^{23,28,29}$ Slope and intercept values were 0.738 and 0.222 , respectively.

\section{Precision and accuracy}

Intra-day and inter-day precision and accuracy were established by analyzing samples $(n=5)$ at three different concentrations $\left(1.15,6.25\right.$ and $\left.50.00 \mu \mathrm{g} \mathrm{L}^{-1}\right)$, in two consecutive days (Table 2). The inter-day precision for the synthetic samples $\left(1.15,6.25\right.$ and $\left.50.00 \mu \mathrm{g} \mathrm{L}^{-1}\right)$ was between 9.60 and $10.40 \%$, while the accuracy for the same concentration levels of the synthetic samples was between 82.15 and $89.90 \%$. All the values obtained were satisfactory and within the guidelines provided by the US EPA $8000 \mathrm{D}^{20}$ method (precision values less than $20 \%$; accuracy values between 70 and $130 \%) .{ }^{20}$ The precision and accuracy values of the method are quite consistent with methods available in the literature (85-99.3\%). . $3,24,28,30,31$

Our analytical method represents a simple and rapid procedure for the determination of 4-NP in surface waters samples with good accuracy, precision, LOD and LOQ compatible with the values found in the literature. The extraction procedure involving the SPE allows efficient recovery of 4-NP from the matrix (greater than 85\%), consuming low volume of organic solvent and generating minimum residue, according to the principles of green chemistry. Since all the above-mentioned validation parameters met the requirements of the US EPA method $8000,{ }^{20}$ such method can be proposed as a useful procedure for the routine analysis of the examined compound.

\section{Sampling analysis}

The validated method was applied to the determination of 4-NP in surface water samples from the Guandu basin (Guandu River and affluents), in the metropolitan region of Rio de Janeiro State. The physico-chemical characteristics ( $\mathrm{pH}$, conductivity, temperature and humidity) of these samples were also determined.

Samples were collected in the metropolitan area of Rio de Janeiro between April-June 2015 and analyzed for 4-NP. The results can be seen in Table 3. From a total of 19 collected samples, 4-nonylphenol was detected 
Table 3. Determination of nonylphenol in the water samples collected in the Guandu River basin

\begin{tabular}{lccccccc}
\hline & \multicolumn{7}{c}{ Concentration / $\left(\mu \mathrm{g} \mathrm{L}{ }^{-1}\right)$} \\
\cline { 2 - 7 } & Queimados & Japeri & Santa Cruz & Seropédica & Piraí & Paracambi & Itaguaí \\
\hline April & $\mathrm{d}$ & $\mathrm{nd}$ & $\mathrm{d}$ & $\mathrm{d}$ & $\mathrm{d}$ & $\mathrm{d}$ & $\mathrm{nc}$ \\
May & $\mathrm{d}$ & $\mathrm{nd}$ & $\mathrm{d}$ & $\mathrm{d}$ & $\mathrm{d}$ & $\mathrm{d}$ & $\mathrm{nc}$ \\
June & $\mathrm{nd}$ & $\mathrm{nd}$ & 1.73 & $\mathrm{nd}$ & $\mathrm{d}$ & $\mathrm{d}$ & $\mathrm{d}$ \\
\hline
\end{tabular}

$\mathrm{d}:<$ method quantification limit (MQL); nd: not detected; nc: not collected.

in $12(63.2 \%)$ samples, quantified in $2(10.5 \%)$ and not detected in $5(26.3 \%)$.

From all the analyzed samples, only 5 could not be detected (nd) with concentration values below the MDL $\left(0.20 \mu \mathrm{g} \mathrm{L}^{-1}\right)$. Only in the municipality of Japeri (P6) there was no detection of the analyte at any evaluated collection time. The occurrence of 4-nonylphenol in the environment is clearly correlated with anthropogenic activities, ${ }^{32,33}$ since 4-NP is a degradation product of a surfactant, which is a significant anthropogenic component of the aquatic environment used in a large number of industries. Thus, a point of sampling away from anthropogenic sources, such as the sampling point in the city of Japeri, may justify the non-detection of 4-NP.

In some samples, 4-NP has been detected but could not be quantified, presenting concentration levels between MDL $\left(0.20 \mu \mathrm{g} \mathrm{L}^{-1}\right)$ and MQL $\left(1.15 \mu \mathrm{g} \mathrm{L}^{-1}\right)$. According to the US EPA guide, ${ }^{20}$ an analyte can be detected within the MDL and MQL range with 99\% confidence, although the quantification within this range does not match the precision and accuracy required. ${ }^{20}$ This region deserves attention, since these surface waters serve as abstraction water for later treatment and distribution to the population.

Santa Cruz (P1) and Paracambi (P5) showed the same profile for 4-NP determination at all evaluated times. For both sampling points, 4-NP was detected in April and May (concentration levels between MDL $(0.20 \mu \mathrm{g} \mathrm{L}-1)$ and MQL $\left.\left(1.15 \mu \mathrm{g} \mathrm{L}^{-1}\right)\right)$ and quantified in June with concentration levels of 1.73 and $2.32 \mu \mathrm{g} \mathrm{L}-1$ for Santa Cruz and Paracambi, respectively.

In Santa Cruz (P1), the main source of nonylphenol in surface water as a whole is related, among other things, to sewage discharges from wastewater treatment plants, a proximity to industrialized and/or urban areas and other anthropogenic connections such as rainwater discharges. ${ }^{33}$ Another sampling point where 4-NP was quantified was in Paracambi (P5). This site is a tributary of the Guandu River, Ribeirão das Lajes River. The presence of this contaminant could be explained by the presence of a textile factory in this city operated between 1876 and 1996. Nonionic surfactants like ethoxylated alkylphenols are widely used in textile factory, due to their wetting, dispersing and ability to promote tissue softness. ${ }^{34,35}$ Persistent organic pollutants are toxic to living beings, accumulating in microorganisms, plants and animals. They are not eliminated by the organisms over time, and are resistant to chemical, biological and photolytic degradations. ${ }^{36}$

\section{Conclusions}

4-NP was determined by liquid chromatography with ultraviolet detection, providing a simple and rapid procedure for the determination of this compound in surface waters samples. Such analytical method was useful as a tool for monitoring 4-NP in surface waters at concentration levels above ca. $1 \mu \mathrm{g} \mathrm{L}^{-1}$, being able to detect and quantify 4-NP in six sampling points of the Guandu River basin. In order to determine 4-NP in surface water samples at lower concentration levels, our method can also be extended by applying higher concentration factors. Based on these findings and the lack of regulation in Brazil, a continuous monitoring of 4-NP in environmental samples is required.

\section{Acknowledgments}

The authors acknowledge the financial support and fellowships granted by the Brazilian agencies CAPES and CNPq. Part of this work was possible thanks to the announcement 002/2014, Aid to Research for Elaboration of Studies of the Association of Water Management of the Paraíba do Sul River Watershed (AGEVAP), which allowed the collection of samples during this work.

\section{References}

1. Godoi, A. F. L.; Favoreto, R.; Santiago-Silva, M.; Quim. Nova 2003, 26, 708.

2. Mello-da-Silva, C. A.; Fruchtengarten, L.; J. Pediatr. (Rio J.) 2005, 81, S205.

3. Terzopoulou, E.; Voutsa, D.; Kaklamanos, G.; Environ. Sci. Pollut. Res. Int. 2015, 22, 1095. 
4. Mnif, W.; Hassine, A. I. H.; Bouaziz, A.; Bartegi, A.; Thomas, O.; Roig, B.; Int. J. Environ. Res. Public Health 2011, 8, 2265.

5. Previdello, B. A. F.; de Carvalho, F. R.; Tessaro, A. L.; de Souza, V. R.; Hioka, N.; Quim. Nova 2006, 29, 600.

6. Trinh, H. T.; Duong, H. T.; Ta, T. T.; Cao, H. V.; Strobel, B. W.; Le, G. T.; Environ. Sci. Pollut. Res. 2017, 24, 19338.

7. Aloui, F.; Kchaou, S.; Sayadi, S.; J. Hazard. Mater. 2009, 164, 353.

8. Renner, R.; Environ. Sci. Technol. 1997, 31, 316A.

9. Solé, M.; de Alda, M. J. L.; Castillo, M.; Porte, C.; LadegaardPedersen, K.; Barceló, D.; Environ. Sci. Technol. 2000, 34, 5076.

10. Zgoła-Grześkowiak, A.; Grześkowiak, T.; Rydlichowski, R.; Łukaszewski, Z.; Chemosphere 2009, 75, 513.

11. Fiedler, S.; Foerster, M.; Glaser, B.; Zech, W.; Chemosphere 2007, 66, 212.

12. Errico, S.; Nicolucci, C.; Migliaccio, M.; Micale, V.; Mita, D. G.; Diano, N.; Mar. Pollut. Bull. 2017, 120, 68.

13. Montagner, C. C.; Jardim, W. F.; J. Braz. Chem. Soc. 2011, 22, 1452.

14. Sodré, F. F.; Pescara, I. C.; Montagner, C. C.; Jardim, W. F.; Microchem. J. 2010, 96, 92.

15. Jardim, W. F.; Montagner, C. C.; Pescara, I. C.; Umbuzeiro, G. A.; Di Dea Bergamasco, A. M.; Eldridge, M. L.; Sodré, F. F.; Sep. Purif. Technol. 2012, 84, 3.

16. Machado, K. C.; Grassi, M. T.; Vidal, C.; Pescara, I. C.; Jardim, W. F.; Fernandes, A. N.; Sodré, F. F.; Almeida, F. V.; Santana, J. S.; Canela, M. C.; Nunes, C. R. O.; Bichinho, K. M.; Severo, F. J. R.; Sci. Total Environ. 2016, 572, 138.

17. Moreira, D. S.; Aquino, S. F.; Afonso, R. J. C. F.; Santos, E. P. P. C.; de Pádua, V. L.; Environ. Technol. 2009, 30, 1041.

18. Moreira, M.; Aquino, S.; Coutrim, M.; Silva, J.; Afonso, R.; Environ. Technol. 2011, 32, 1409.

19. Agência Nacional de Águas (ANA); Plano Estratégico de Recursos Hídricos das Bacias Hidrográficas dos Rios Guandu, da Guarda e Guandu Mirim; ANA: Brasília, 2007.

20. United States Environmental Protection Agency (US EPA); SW-846 Test Method 8000D: Determinative Chromatographic Separations; US EPA: Washington, D.C., 2014.
21. United States Environmental Protection Agency (US EPA); $S W$ 846 Test Method 8310: Polynuclear Aromatic Hydrocarbons; US EPA: Washington, D.C., 1986,

22. Shih, H. K.; Shu, T. Y.; Ponnusamy, V. K.; Jen, J. F.; Anal. Chim. Acta 2015, 854, 70.

23. Neng, N. R.; Nogueira, J. M. F.; Molecules 2014, 19, 9369.

24. Zhou, Q.; Lei, M.; Li, J.; Zhao, K.; Liu, Y.; Sep. Purif. Technol. 2017, 182, 78.

25. United States Environmental Protection Agency (US EPA); EPA-822-R-05-005: Aquatic Life Ambient Water Quality Criteria - Nonylphenol; US EPA, Office of Water, Office of Science and Technology: Washington, DC, 2002, p. 36.

26. Azevedo, D. A.; Lacorte, S.; Viana, P.; Barceló, D.; J. Braz. Chem. Soc. 2001, 12, 532.

27. Spadoto, M.; Sueitt, A. P. E.; Galinaro, C. A.; Pinto, T. S.; Pompei, C. M. E.; Botta, C. M. R.; Vieira, E. M.; Drug Chem. Toxicol., in press, DOI: 10.1080/01480545.2017.1381109.

28. Sun, A.; Xu, Q.; Yu, X.; Pol. J. Environ. Stud. 2013, 22, 899.

29. Cai, Y.; Jiang, G.; Liu, J.; Zhou, Q.; Anal. Chem. 2003, 75, 2517.

30. Camilleri, J.; Baudot, R.; Wiest, L.; Vulliet, E.; Cren-Olivé, C.; Daniele, G.; Int. J. Environ. Anal. Chem. 2014, 95, 67.

31. Esteban, S.; Gorga, M.; Petrovic, M.; González-Alonso, S.; Barceló, D.; Valcárcel, Y.; Sci. Total Environ. 2014, 466-467, 939.

32. Zembrzuska, J.; Budnik, I.; Lukaszewski, Z.; J. Environ. Manage. 2016, 169, 247.

33. Soares, A.; Guieysse, B.; Jefferson, B.; Cartmell, E.; Lester, J. N.; Environ. Int. 2008, 34, 1033.

34. Moore, S. B.; Ausley, L. W.; J. Cleaner Prod. 2004, 12, 585.

35. Felix, F. F.; Navickiene, S.; Dórea, H. S.; Rev. Fapese 2007, 3, 39.

36. Petrovic, M.; Barceló, D.; Diaz, A.; Ventura, F.; J. Am. Soc. Mass Spectrom. 2003, 14, 516.

Submitted: August 16, 2017 Published online: April 13, 2018 